\title{
Evaluation of the cost of producing wind-generated electricity in Chad
}

\author{
Marcel Hamda Soulouknga ${ }^{1,5} \cdot$ Sunday Olayinka Oyedepo $o^{2,5} \cdot$ Serge Yamigno Doka ${ }^{3,5} \cdot$ Timoleon Crépin Kofane $e^{4,5}$
}

Received: 25 July 2019 / Accepted: 30 December 2019 / Published online: 11 January 2020

(c) The Author(s) 2020

\begin{abstract}
This paper presents an economic analysis of the electricity produced by different types of wind turbines selected for Chad. Thus, the data considered for the analysis in this study are the average monthly wind speeds at selected locations, as well as the altitude value. Statistical analysis was performed using the Weibull distribution. The same energy factor allowed determining the Weibull parameters. The results obtained show that the average annual wind speed varies from $1 \mathrm{~m} / \mathrm{s}$ in Am-Timan to $4.2 \mathrm{~m} / \mathrm{s}$ in N'Djamena, at a height of $10 \mathrm{~m}$ from the ground. Weibull statistical parameters $(k$ and $c)$ were determined at 10,30,50, and $70 \mathrm{~m}$. These were obtained by extrapolation using a power law based on Weibull parameters. Three models of wind turbines available on the market were used in this study: Bonus $300 \mathrm{~kW} / 33$, Bonus $1 \mathrm{MW} / 54$, and Vestas $2 \mathrm{MW} / \mathrm{V} 80$. The performance of these wind turbines was evaluated using the calculation of the capacity factor and the annual energy produced by each type of wind turbine at 12 sites. The PVC (present value) method was used to perform an economic analysis. The lowest cost of wind power generation was obtained with the Vestas $2 \mathrm{MW} / \mathrm{V} 80$ model, with a cost per kilowatt-hour $(\mathrm{kWh})$ of approximately $\$ 143.08 / \mathrm{kWh} /$ year in Moundou and 132343\$89/kWh/year in Am-Timan. Therefore, it is recommended the use of a Vestas $2 \mathrm{MW} / 80$ wind turbine in Chad.
\end{abstract}

Keywords Weibull distribution $\cdot$ Wind turbine $\cdot \mathrm{PVC} \cdot$ Wing energy

\section{List of symbols}

$v \quad$ Wind speed

$f(v) \quad$ Probability of observing wind speed $(v)$

$p(v) \quad$ Wind power

$P_{\text {er }} \quad$ Rated wind turbine power

$V_{\mathrm{c}} \quad$ Cut-in wind speed

$V_{\mathrm{r}} \quad$ Rated wind speed

$V_{\mathrm{f}} \quad$ Cut-off wind speed

$C_{\mathrm{f}} \quad$ Capacity factor

$E_{\mathrm{wt}} \quad$ Accumulated annual energy out put

Marcel Hamda Soulouknga

marcelhamda@yahoo.fr

1 Ecole Normale Supérieure de l'Enseignement Technique de Sarh, Sarh, Chad

2 Mechanical Engineering Department, Covenant University, Ota, Nigeria

3 Department of Physics, Faculty of Science, University of Ngaoundéré, PO Box 454, Ngaoundere, Cameroon

4 Department of Physics, Faculty of Science, The University of Yaounde I, P.O. Box. 812, Yaoundé, Cameroon

5 Centre d'Excellence Africain en Technologie de l'Information et de la Communication, The University of Yaounde I, P.O. Box. 812, Yaoundé, Cameroon

\section{Introduction}

The possibility of exploiting renewable energies for electricity generation has been considered by different researchers across the globe because of the negative effects of fossil fuels on the environment. Among the many clean sources of energy is wind energy which has developed very rapidly over the past 2 decades. Great technological progress has been made to reduce the cost of producing wind-generated electricity [1]. The turbine is free of fossil fuel energy and, hence, does not cause an environmental pollution when generating electricity [2]. Similarly, it can produce wind power near load centers, eliminating transmission loss in rural and urban landscape lines [3]. In developing countries, it is important to study and carefully understand the energy model to ensure a good standard of living and to alleviate poverty $[4,5]$.

Speed, direction, continuity, and availability are the characteristics of the wind that can be developed to determine the wind energy potential of a site $[6,7]$. In many countries around the world, studies and assessments of wind characteristics and the potential of wind energy are being conducted. Countries like Hong Kong Islands have its wind analysis discussed by Lu et al. [8]. Youm et al. presented wind energy 
potential in Senegal and the analysis of wind data using the Weibull probability distribution [9]. Mostafaeipour et al. [10] evaluated wind energy resources for selected sites in Iran. Shaahid et al. [11] studied the economic feasibility of the development of wind power plants in coastal areas of Saudi Arabia. Dursic et al. [12] evaluated the wind energy source in the southern Banat region as a surbie. Statistical analyses focused on the measurement of wind parameters such as mean wind speed, power density, direction, and Weibull distribution parameters. A mathematical method of the sum of the least squares is used to analyze the vertical profile of the wind speed. Alami Els [13] in the Gulf of Tunis in Tunisia during their study on the potential of wind resources considered the hourly data of the wind speed and wind direction every $10 \mathrm{~min}$ to assess the wind potential. Worked on the evaluation of wind energy and electricity generation in the Gulf of Tunis, Tunisia. Four different methods were used to determine the Weibull parameters [14]. Worked on the energy balance of the first wind farm of Sidi Daoud in Tunisia. Thus, based on wind speed data measured over a 5-year period. The wind potential of the Sidi Daoud site is analyzed statistically using the Weibull and Rayleigh parameters [15]. Sidi Daoud [15, 16], El-Kefregion [17], and Tunisia $[18,19]$ in the literature have assessed the potential for wind power and electricity production in 2011 in BorjCedria [20]. For the long-term prediction of electrical energy consumption, they have made a study on the approach based on gene expression. To identify the most important independent variables affecting electricity demand, a sensitivity analysis was performed [21]. Conducted an optimization study based on NSGA-II and MOPSO for sizing a hybrid $\mathrm{PV} /$ wind/battery energy storage system. To determine the optimal number of PV panels and wind farm system, the optimized hybrid system was examined in MATLAB [22]. Worked on short-term electricity price forecasting using the hybrid backtracking algorithm and the ANFIS approach. Thus, a hybrid machine learning algorithm and a search algorithm in the learning process of the ANFIS approach have been developed to predict the price of electricity more precisely [23]. Conducted a study on solving the problem of sending non-convex economic load via an artificial algorithm for cooperative research. Thus, they used a method that is to interfere and work with feasible solutions throughout the optimization [24]. As an indication, in 2009, the population of Chad was estimated at 11,039,873 inhabitants, at a growth rate of $6 \%$ per year. As a result, current statistics estimate this population at $15,177,557$. In Chad, making electricity available everywhere has always been an important socio-economic issue. However, despite the considerable efforts made by the public authorities, the population still encounters many difficulties in accessing electricity. In other words, Chad is one of the poorest-supplied countries in the Economic and Monetary Community of Central Africa
(CEMAC) sub-region [25]: less than 5\% of the population has access to electricity, mainly in the urban areas (2017), $80 \%$ of the country's consumption is in N'Djamena, load shedding is common, because the grid does not provide enough electricity; there is still no national interconnection of the network; domestic wood accounts for $90 \%$ of primary energy consumption. Since no study has been conducted to estimate the cost of a wind turbine in Chad, this work is on the determination of Weibull parameters in evaluating wind characteristics in Chad. Also, economic analysis of wind power generation considering three turbines models for the selected locations is carried out using present value cost (PVC) method.

\section{Methodology}

\section{Presentation of Chad}

A landlocked country in Central Africa, Chad is located between $7^{\circ}$ and $24^{\circ}$ north latitude and $13^{\circ}$ and $24^{\circ}$ east longitude (Fig. 1). It is bordered, in the North with Libya, in the East with Sudan, in the South with the Central African Republic, and in the West with Cameroon, Niger and Nigeria (countries with which it shares Lake Chad). The nearest port, Douala, is $1700 \mathrm{~km}$ from N'Djamena, the capital. The Chadian population is estimated at 11.5 million inhabitants in 2011 (i.e., 27.2\% of the population of the CEMAC zone). It is relatively young, and a large majority live in rural areas. Although on a downtrend, population growth is $2.6 \%$ on average each year.

\section{Wind characteristic of the selected locations}

The wind data used were obtained from the National Office of Meteorology (ONM). These are monthly wind speed data measured for 12 sites. Geographic coordinates are shown in Table 1.

\section{Statistical analysis of wind data}

To estimate the variations of the wind speed, we used the Weibull probability function which is represented by the following equation $[26,27]$ :

$f(v)=\left(\frac{k}{c}\right) \cdot\left(\frac{v}{c}\right)^{(k-1)} \cdot \exp \left(-\left(\frac{v}{c}\right)^{k}\right),(k>0, v>0, c>1)$,

where $v$ is the wind speed $(\mathrm{m} / \mathrm{s}), c$ is the scale parameter $(\mathrm{m} / \mathrm{s})$, and $k$ is the shape parameter (dimensionless). 


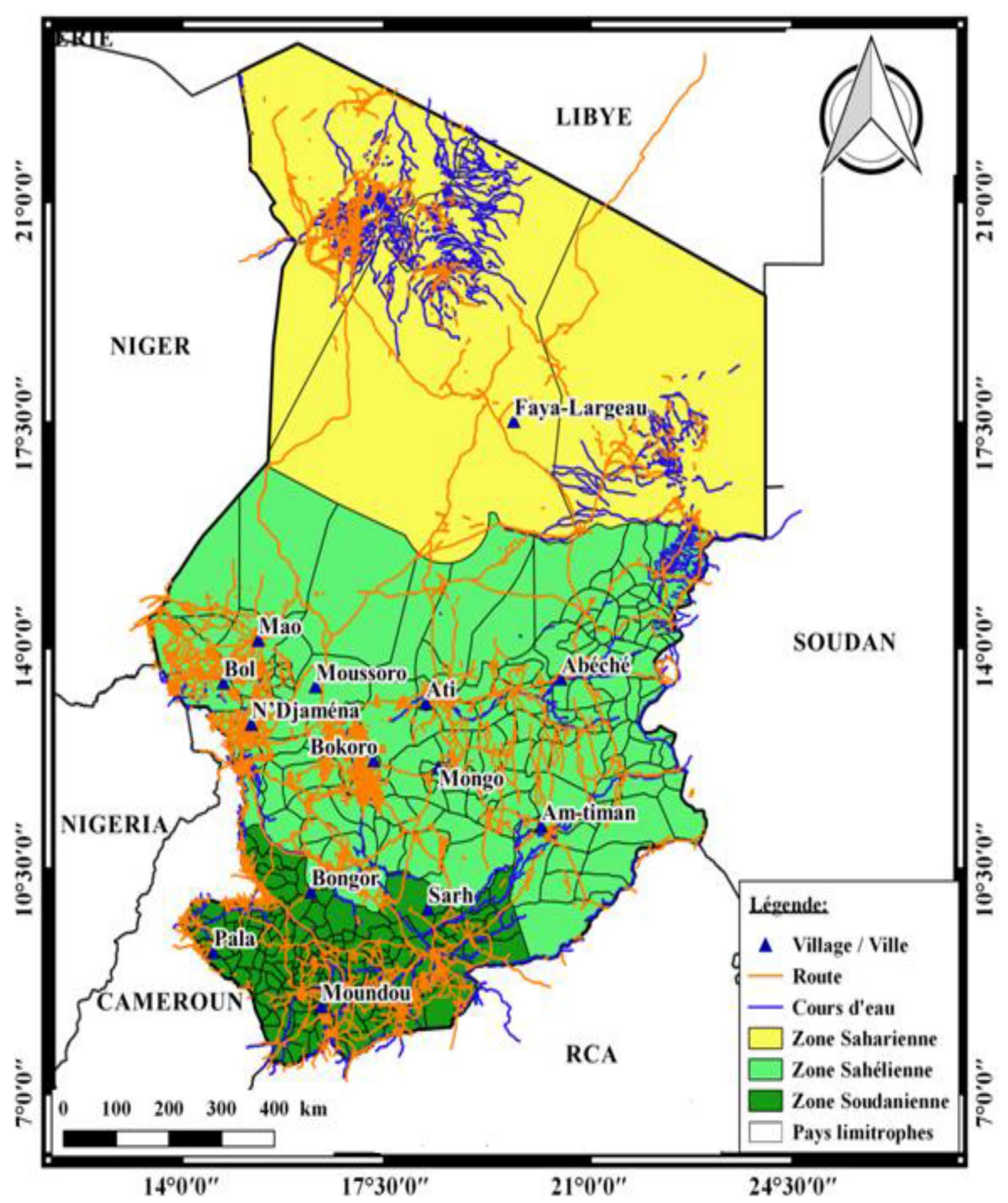

Fig. 1 Map of Chad

\section{Extrapolation of wind speed at different heights}

Wind speed is generally measured at $10 \mathrm{~m}$ height, while the installation height of wind turbines is always higher than this height. Moreover, the wind speed increases with the altitude because of the existence of the atmospheric boundary layer, it is necessary to extrapolate the measured wind speed up to the hub height of the wind turbine. The most commonly used method for this purpose is the power law [28]. It is expressed by the following relation [29]:

$$
v\left(z_{2}\right)=v\left(z_{10}\right)\left(\frac{z_{2}}{z_{10}}\right)^{m}
$$


Table 1 Geographical coordinates of stations used in the study

\begin{tabular}{|c|c|c|c|c|c|c|}
\hline Zones & Station & Longitude $\left({ }^{\circ} \mathrm{E}\right)$ & Latitude $\left({ }^{\circ} \mathrm{N}\right)$ & Elevation (m) & $\begin{array}{l}\text { Period of measure- } \\
\text { ment (year) }\end{array}$ & $\begin{array}{l}\text { Height of } \\
\text { the mast } \\
\text { (m) }\end{array}$ \\
\hline \multirow[t]{4}{*}{ Saharan zone } & Faya-Largeau & 19.7 & 17.55 & 233 & 18 & 10 \\
\hline & Abeche & 20.51 & 13.51 & 545 & 26 & 10 \\
\hline & Bokoro & 17.3 & 12.23 & 300 & 18 & 10 \\
\hline & N'Djamena & 15.2 & 12.8 & 294 & 20 & 10 \\
\hline \multirow[t]{6}{*}{ Sahelian zone } & Mongo & 18.41 & 12.11 & 430 & 30 & 10 \\
\hline & Ati & 18.19 & 13.13 & 334 & 19 & 10 \\
\hline & Mao & 15.32 & 14.12 & 356 & 9 & 10 \\
\hline & Bol & 14.72 & 13.45 & 291 & 9 & 10 \\
\hline & Am-Timan & 20.17 & 11.2 & 432 & 28 & 10 \\
\hline & Moundou & 16.4 & 8.37 & 420 & 20 & 10 \\
\hline \multirow[t]{2}{*}{ Sudanese zone } & Pala & 14.55 & 9.22 & 420 & 30 & 10 \\
\hline & Sarh & 18.23 & 9.9 & 364 & 20 & 10 \\
\hline
\end{tabular}

$m=\frac{\left[0.37-0.088 \ln \left(v_{10}\right)\right]}{\left[1-0.088 \ln \left(\frac{z_{10}}{10}\right)\right]}$.

The Weibull parameters at the measured height are related to the parameters at the height of the wind turbine by the following expressions:

$c(h)=c_{0}\left(\frac{h}{h_{0}}\right)^{n}$

$k(h)=k_{0}\left[1-0.088 \ln \left(\frac{h_{0}}{10}\right)\right] /\left[1-0.088 \ln \left(\frac{h}{10}\right)\right]$,

where $c_{0}$ and $k_{0}$ are the scale factor and the shape parameter, respectively, at the measured height $h_{0}$, and $h$ is the height of the concentrator.

\section{Estimation of electrical energy supplied by wind turbines}

The performance of the wind turbines is estimated with the capacity factor $\left(C_{\mathrm{f}}\right)$ which represents the fraction of the average power supplied by the wind turbine $\left(P_{\mathrm{e}, \text { moy }}\right)$ compared to the nominal power of the wind turbine $\left(P_{\mathrm{eR}}\right)$. The average power $\left(P_{\mathrm{e}, \mathrm{Avg}}\right)$ and the capacity factor of wind turbines are calculated using the following equations [30, 31]:

$P_{\mathrm{e}}= \begin{cases}0 & \left(v<v_{\mathrm{c}}\right) \\ P_{\mathrm{eR}} \frac{v^{k}-v_{\mathrm{c}}^{k}}{v_{\mathrm{R}}^{k}-v_{\mathrm{c}}^{k}} & \left(v_{\mathrm{c}} \leq v \leq v_{\mathrm{R}}\right) \\ P_{\mathrm{eR}} & \left(v_{\mathrm{R}} \leq v \leq v_{\mathrm{F}}\right) \\ 0 & \left(v_{\mathrm{F}}<v\right)\end{cases}$
$P_{\mathrm{e}, \mathrm{ave}}=P_{\mathrm{eR}}\left\{\frac{\mathrm{e}^{-\left(\frac{v_{\mathrm{c}}}{c}\right)^{k}}-\mathrm{e}^{-\left(\frac{v_{\mathrm{r}}}{c}\right)^{k}}}{\left(\frac{v_{\mathrm{r}}}{c}\right)^{k}-\left(\frac{v_{\mathrm{c}}}{c}\right)^{k}}-\mathrm{e}^{-\left(\frac{v_{\mathrm{r}}}{c}\right)^{k}}\right\}$,

and the capacity factor $C_{\mathrm{f}}$ of a wind turbine is given by:

$C_{\mathrm{f}}=\frac{P_{\mathrm{e}, \mathrm{ave}}}{P_{\mathrm{eR}}}$,

where $V_{\mathrm{c}}, V_{\mathrm{r}}$, and $V_{\mathrm{f}}$, are the zero flow wind speed, the nominal wind speed, and the shutdown speed of the wind turbine, respectively.

Annual cumulative energy production (AEP) is then estimated using equation [30]:

$E_{\text {out }}=P($ e,avg $) \times 8760$.

The availability of the wind power resource for generating electricity is taken as $A=75 \%$ and the total energy output over the WT lifetime is computed as:

$E_{\mathrm{WT}}=8760 \times A \times n \times P_{\mathrm{r}} \times C_{\mathrm{f}}$.

\section{Economic analysis of wind energy}

According to $[32,33]$, the main parameters governing the cost of producing wind energy are as follows:

- Investment costs (including ancillary fees for foundations, network connection, etc.);

- Operating and maintenance costs;

- Electricity generation/average wind speed;

- The life of the turbine;

- The discount rate. 
These factors may vary from country to country and region to region. However, of all the parameters listed, the price of the wind turbine and other capital costs are the most important. According to [32,33], the specific cost of a wind turbine varies considerably from one manufacturer to another as shown in Table 2. The choice of the ideal wind turbine is, therefore, essential to ensure economic viability, while the production of electricity is highly dependent on wind conditions. Several methods discussed in [34] have been used in the literature for calculating the cost of wind energy. The PVC method is adopted in this study, because (1) it considers the dynamic development of relevant economic factors and (2) the different cost and income variables, which are taken into account regardless of whether the money has been or will be paid or received in the past or in the future, by deducting the accumulated cost of interest (discounting) of all payment flows at a common reference time [34]. The present value of costs (PVC) is determined using relationship [35]:

$\mathrm{PVC}=1+C_{\mathrm{om}} \times\left[\frac{1+i}{r-i}\right] \times\left[1-\left(\frac{1+i}{1+r}\right)^{n}\right]-S \times\left(\frac{1+i}{1+r}\right)^{n}$,

where $r$ represents the interest rate, $i$ the rate of inflation, $t$ the life of the wind turbine, and $S$ the additional costs and includes the costs of operation, maintenance, and repair.

Table 2 Variation in the cost of wind turbines with rated power [34]

\begin{tabular}{lll}
\hline WT size $(\mathrm{kW})$ & Specific cost per kW & $\begin{array}{l}\text { Average } \\
\text { specific per } \\
\mathrm{kW}\end{array}$ \\
\hline$<20$ & $2200-3000$ & 2600 \\
$20-200$ & $1250-2300$ & 1775 \\
$>200$ & $700-1600$ & 1150 \\
\hline
\end{tabular}

To estimate PVC, the following quantities and assumptions are retained $[35,36]$ :

$r=\frac{i_{0}-i}{1+i}$

In Table 2, it is found that the cost per $\mathrm{kW}$ decreases with the increase in the size of the wind turbine. For the machine size above $200 \mathrm{~kW}$, the average cost of a wind turbine is in the order of $\$ 1150 / \mathrm{kW}$.

The cost of energy (COE) in $\mathrm{kW}$ produced is determined by the following expression [37]:

$\operatorname{COE}(\$ / \mathrm{kWh})=\mathrm{PVC} / \mathrm{E}_{\mathrm{WT}}$.

\section{Results and discussion}

\section{Estimation of wind resources}

\section{Average wind speed}

The monthly wind speed for 12 selected sites at $10 \mathrm{~m}$ altitude is presented in Table 3. It is noted that the least wind speed of $1 \mathrm{~m} / \mathrm{s}$ is observed in Am-Timan in August, September, and October, while the highest of $4.2 \mathrm{~m} / \mathrm{s}$ is recorded in N'Djamena in March.

\section{Weibull $k$ parameters at $10 \mathrm{~m}$ altitude}

Table 4 presents the Weibull $k$ parameter at $10 \mathrm{~m}$ altitude. From Table 4, it can be seen that the least value of the form parameter $(k)$ of the Weibull distribution of 1.062 is recorded at Am-Timan, while the highest value of 4.907 is observed at Mao in September.
Table 3 Values of the wind speed at $10 \mathrm{~m}$ altitude

\begin{tabular}{llllllllllllll}
\hline$v(\mathrm{~m} / \mathrm{s})$ & Jan & Feb & Mar & Apr & May & Jun & Jul & Aug & Sep & Oct & Nov & Dec & Aver \\
\hline Abeche & 2.7 & 2.8 & 3.1 & 3 & 2.7 & 2.4 & 2.6 & 2.1 & 2 & 2.6 & 2.9 & 2.8 & 2.642 \\
Am-Timan & 1.5 & 1.6 & 1.4 & 1.5 & 1.7 & 1.5 & 1.3 & 1 & 1 & 1 & 1.2 & 1.4 & 1.342 \\
Bokoro & 1.7 & 1.9 & 1.9 & 1.7 & 1.7 & 1.7 & 1.6 & 1.3 & 1.2 & 1.2 & 1.5 & 1.6 & 1.583 \\
Mongo & 2.2 & 2.7 & 3.1 & 3.1 & 3.1 & 2.9 & 2.5 & 2.1 & 1.8 & 2.3 & 2.5 & 2.2 & 2.542 \\
N'Djamena & 3.6 & 4 & 4.2 & 3.2 & 3.2 & 3.6 & 3.2 & 2.5 & 2.4 & 2.4 & 3.3 & 3.4 & 3.25 \\
Faya & 4 & 3.8 & 3.7 & 3.3 & 2.9 & 2.7 & 2.3 & 2.2 & 3 & 3.4 & 3.9 & 3.8 & 3.25 \\
Moundou & 3.1 & 3.3 & 3.1 & 3.3 & 2.9 & 2.8 & 2.7 & 2.3 & 2.1 & 2 & 2.1 & 2.6 & 2.692 \\
Pala & 2.6 & 2.9 & 2.9 & 2.8 & 2.7 & 2.4 & 2.1 & 1.7 & 1.7 & 1.9 & 2 & 2.3 & 2.333 \\
Sarh & 1.9 & 2.2 & 2.4 & 3.2 & 2.3 & 2 & 1.7 & 1.4 & 1.4 & 1.4 & 1.4 & 1.6 & 1.908 \\
Bol & 2.2 & 2.2 & 2.2 & 2 & 1.9 & 2 & 2.2 & 1.8 & 1.5 & 1.8 & 2.2 & 2.2 & 2.017 \\
Mao & 2.4 & 2.5 & 2.6 & 2.2 & 2.1 & 2.1 & 2.1 & 1.8 & 1.8 & 2.1 & 2.4 & 2.5 & 2.217 \\
Ati & 1.7 & 1.9 & 2 & 1.8 & 1.8 & 1.8 & 1.8 & 1.4 & 1.4 & 1.5 & 1.7 & 1.8 & 1.717 \\
\hline
\end{tabular}


Table 4 Form parameter values $k$ at $10 \mathrm{~m}$ altitude

\begin{tabular}{lllllllllllll}
\hline$k(\mathrm{~m} / \mathrm{s})$ & Jan & Feb & Mar & Apr & May & Jun & Jul & Aug & Sep & Oct & Nov & Dec \\
\hline Abeche & 3.051 & 3.513 & 3.187 & 3.547 & 3.051 & 3.083 & 3.118 & 2.789 & 2.786 & 3.292 & 3.76 & 3.59 \\
Am-Ti & 1.094 & 1.062 & 4.544 & 4.431 & 1.527 & 2.13 & 2.454 & 3.563 & 3.183 & 2.441 & 1.201 & 1.175 \\
Bokoro & 3.84 & 3.403 & 4.086 & 4.294 & 3.84 & 3.944 & 3.476 & 3.272 & 3.755 & 3.498 & 3.911 & 3.803 \\
Mongo & 3.811 & 3.482 & 3.833 & 3.541 & 3.078 & 3.091 & 2.931 & 2.873 & 2.658 & 3.364 & 3.632 & 3.262 \\
N'Djamena & 4.621 & 4.202 & 4.47 & 3.926 & 4.31 & 4.683 & 4.368 & 4.081 & 4.093 & 3.528 & 4.407 & 4.097 \\
Faya-Larg & 3.783 & 3.679 & 3.012 & 3.92 & 3.628 & 3.774 & 3.634 & 3.554 & 3.563 & 4.04 & 4.19 & 4.181 \\
Moundou & 3.613 & 3.242 & 3.256 & 2.876 & 3.028 & 3.144 & 3.306 & 2.705 & 3.058 & 2.397 & 3.235 & 3.355 \\
Pala & 3.193 & 3.539 & 3.143 & 3.205 & 3.482 & 3.277 & 3.983 & 3.559 & 3.108 & 3.646 & 2.64 & 2.263 \\
Sarh & 1.194 & 1.232 & 1.307 & 1.621 & 3.396 & 3.73 & 3.741 & 3.144 & 3.144 & 2.924 & 1.678 & 1.294 \\
Bol & 4.868 & 4.521 & 4.654 & 4.12 & 4.258 & 4.428 & 4.587 & 4.162 & 3.911 & 4.605 & 4.458 & 4.163 \\
Mao & 4.308 & 4.433 & 4.765 & 4.587 & 4.907 & 4.364 & 4.507 & 4.863 & 5.149 & 4.739 & 4.093 & 4.75 \\
Ati & 2.871 & 2.808 & 2.883 & 2.621 & 2.697 & 2.697 & 2.867 & 3.144 & 3.144 & 2.616 & 2.177 & 2.779 \\
\hline
\end{tabular}

\section{Weibull $c$ parameters at $10 \mathrm{~m}$ altitude}

Table 5 presents the monthly values of the scale parameter of the Weibull distribution. Thus, the least value of $1.11 \mathrm{~m} / \mathrm{s}$ is recorded at Am-Timan and the highest value of $4.604 \mathrm{~m} / \mathrm{s}$ is observed in N'Djamena.

\section{Extrapolation of data at different altitudes}

Wind data from the ONM were used to determine monthly variations of statistical parameters at $10 \mathrm{~m}$ in height. These quantities are then extrapolated to 30,50 and $70 \mathrm{~m}$ in height.

\section{Extrapolation of wind speed to 30.50 , and $67 \mathrm{~m}$ altitude}

The average wind speed at $30 \mathrm{~m}$ altitude is presented in Table 6. From Table 6, it can be seen that the minimum speed of $1.502 \mathrm{~m} / \mathrm{s}$ is recorded at Am-Timan in the months of August, September, and October, while the maximum speed of $5.490 \mathrm{~m} / \mathrm{s}$ is recorded in the month of March in N'Djamena.

\section{Extrapolation of the wind speed to $50 \mathrm{~m}$ altitude}

Table 7 presents the average wind speed at altitude of $50 \mathrm{~m}$. From Table 7, it can be seen that the minimum average wind speed of $1.814 \mathrm{~m} / \mathrm{s}$ is recorded in Am-Timan in August, September, and October, while the maximum speed of $6.217 \mathrm{~m} / \mathrm{s}$ is recorded in N'Djamena in March.

Table 8 shows the extrapolation of the wind speed to $67 \mathrm{~m}$ altitude. Minimum speed of $2.021 \mathrm{~m} / \mathrm{s}$ is recorded in the months of August, September, and October in Am-Timan. The maximum speed of $6.677 \mathrm{~m} / \mathrm{s}$ is recorded in the month of March in N'Djamena. It can be deduced that the wind speed increases with altitude.

\section{Extrapolation of the Weibull $k$ and $c$ parameters}

Table 9 presents the extrapolation of the shape parameter at $30 \mathrm{~m}$ altitude. From Table 9, it can be seen that the least 1
Table 5 Parameter values $c$ at $10 \mathrm{~m}$ altitude

\begin{tabular}{lllllllllllll}
\hline$c(\mathrm{~m} / \mathrm{s})$ & Jan & Feb & Mar & Apr & May & Jun & Jul & Aug & Sept & Oct & Nov & Dec \\
\hline Abeche & 3.021 & 3.111 & 3.461 & 3.332 & 3.021 & 2.684 & 2.906 & 2.358 & 2.246 & 2.898 & 3.21 & 3.107 \\
Am-Timan & 1.551 & 1.638 & 1.533 & 1.645 & 1.887 & 1.693 & 1.466 & 1.11 & 1.117 & 1.128 & 1.276 & 1.48 \\
Bokoro & 1.88 & 2.115 & 2.093 & 1.868 & 1.88 & 1.877 & 1.779 & 1.45 & 1.328 & 1.334 & 1.657 & 1.77 \\
Faya-Larg & 4.426 & 4.212 & 4.142 & 3.645 & 3.217 & 2.988 & 2.551 & 2.443 & 3.331 & 3.749 & 4.291 & 4.181 \\
Mongo & 2.434 & 3.001 & 3.428 & 3.443 & 3.467 & 3.243 & 2.802 & 2.356 & 2.025 & 2.561 & 2.773 & 2.454 \\
N'Djamena & 3.938 & 4.4 & 4.604 & 3.534 & 3.515 & 3.935 & 3.512 & 2.755 & 2.644 & 2.666 & 3.62 & 3.746 \\
Moundou & 3.439 & 3.682 & 3.458 & 3.702 & 3.246 & 3.128 & 3.009 & 2.586 & 2.349 & 2.256 & 2.343 & 2.896 \\
Pala & 2.903 & 3.221 & 3.24 & 3.126 & 3.001 & 2.676 & 2.317 & 1.888 & 1.9 & 2.107 & 2.25 & 2.596 \\
Sarh & 2.017 & 2.353 & 2.601 & 3.573 & 2.56 & 2.215 & 1.882 & 1.564 & 1.564 & 1.569 & 1.567 & 1.731 \\
Bol & 2.4 & 2.41 & 2.406 & 2.203 & 2.089 & 2.193 & 2.408 & 1.981 & 1.657 & 1.97 & 2.412 & 2.421 \\
Mao & 2.636 & 2.742 & 2.839 & 2.408 & 2.289 & 2.305 & 2.301 & 1.963 & 1.957 & 2.294 & 2.644 & 2.731 \\
Ati & 1.907 & 2.133 & 2.243 & 2.026 & 2.024 & 2.024 & 2.019 & 1.564 & 1.564 & 1.688 & 1.919 & 2.022 \\
\hline
\end{tabular}


Table 6 Mean wind speed at $30 \mathrm{~m}$ altitude

Table 7 Mean wind speed at $50 \mathrm{~m}$ altitude

Table 8 Mean wind speed at $67 \mathrm{~m}$ altitude

\begin{tabular}{lllllllllllll}
\hline Month & Abec & Am-T & Bok & Fay & Mon & Mou & N'Dja & Pala & Sarh & Bol & Mao & Ati \\
\hline Jan & 3.683 & 2.166 & 2.425 & 5.253 & 3.061 & 4.173 & 4.776 & 3.56 & 2.681 & 3.061 & 3.311 & 2.425 \\
Feb & 3.806 & 2.296 & 2.681 & 5.015 & 3.683 & 4.415 & 5.253 & 3.929 & 3.061 & 3.061 & 3.436 & 2.681 \\
Mar & 4.173 & 2.035 & 2.681 & 4.896 & 4.173 & 4.173 & 5.49 & 3.929 & 3.311 & 3.061 & 3.56 & 2.808 \\
Apr & 4.051 & 2.166 & 2.425 & 4.415 & 4.173 & 4.415 & 4.294 & 3.806 & 4.294 & 2.808 & 3.061 & 2.554 \\
May & 3.683 & 2.425 & 2.425 & 3.929 & 4.173 & 3.929 & 4.294 & 3.683 & 3.186 & 2.681 & 2.935 & 2.554 \\
Jun & 3.311 & 2.166 & 2.425 & 3.683 & 3.929 & 3.806 & 4.776 & 3.311 & 2.808 & 2.808 & 2.935 & 2.554 \\
Jul & 3.56 & 1.903 & 2.296 & 3.186 & 3.436 & 3.683 & 4.294 & 2.935 & 2.425 & 3.061 & 2.935 & 2.554 \\
Aug & 2.935 & 1.502 & 1.903 & 3.061 & 2.935 & 3.186 & 3.436 & 2.425 & 2.035 & 2.554 & 2.554 & 2.035 \\
Sept & 2.808 & 1.502 & 1.77 & 4.051 & 2.554 & 2.935 & 3.311 & 2.425 & 2.035 & 2.166 & 2.554 & 2.035 \\
Oct & 3.56 & 1.502 & 1.77 & 4.536 & 3.186 & 2.808 & 3.311 & 2.681 & 2.035 & 2.554 & 2.935 & 2.166 \\
Nov & 3.929 & 1.77 & 2.166 & 5.134 & 3.436 & 2.935 & 4.415 & 2.808 & 2.035 & 3.061 & 3.311 & 2.425 \\
Dec & 3.806 & 2.035 & 2.296 & 5.015 & 3.061 & 3.56 & 4.536 & 3.186 & 2.296 & 3.061 & 3.436 & 2.554 \\
Aver & 3.609 & 1.955 & 2.272 & 4.348 & 3.483 & 3.668 & 4.349 & 3.223 & 2.6835 & 2.828 & 3.08 & 2.445 \\
\hline
\end{tabular}

\begin{tabular}{lllllllllllll}
\hline Mois & Abec & Am-T & Bok & Fay & Mon & Mou & N'Dja & Pala & Sarh & Bol & Mao & Ati \\
\hline Jan & 4.255 & 2.569 & 2.86 & 5.962 & 3.569 & 4.791 & 5.447 & 4.119 & 3.147 & 3.569 & 3.846 & 2.86 \\
Feb & 4.39 & 2.715 & 3.147 & 5.705 & 4.255 & 5.055 & 5.962 & 4.524 & 3.569 & 3.569 & 3.983 & 3.147 \\
Mar & 4.791 & 2.421 & 3.147 & 5.576 & 4.791 & 4.791 & 6.217 & 4.524 & 3.846 & 3.569 & 4.119 & 3.289 \\
Apr & 4.658 & 2.569 & 2.86 & 5.055 & 4.791 & 5.055 & 4.923 & 4.39 & 4.923 & 3.289 & 3.569 & 3.004 \\
May & 4.255 & 2.86 & 2.86 & 4.524 & 4.791 & 4.524 & 4.923 & 4.255 & 3.708 & 3.147 & 3.429 & 3.004 \\
Jun & 3.846 & 2.569 & 2.86 & 4.255 & 4.524 & 4.39 & 5.447 & 3.846 & 3.289 & 3.289 & 3.429 & 3.004 \\
Jul & 4.119 & 2.272 & 2.715 & 3.708 & 3.983 & 4.255 & 4.923 & 3.429 & 2.86 & 3.569 & 3.429 & 3.004 \\
Aug & 3.429 & 1.814 & 2.272 & 3.569 & 3.429 & 3.708 & 3.983 & 2.86 & 2.421 & 3.004 & 3.004 & 2.421 \\
Sept & 3.289 & 1.814 & 2.121 & 4.658 & 3.004 & 3.429 & 3.846 & 2.86 & 2.421 & 2.569 & 3.004 & 2.421 \\
Oct & 4.119 & 1.814 & 2.121 & 5.186 & 3.708 & 3.289 & 3.846 & 3.147 & 2.421 & 3.004 & 3.429 & 2.569 \\
Nov & 4.524 & 2.121 & 2.569 & 5.834 & 3.983 & 3.429 & 5.055 & 3.289 & 2.421 & 3.569 & 3.846 & 2.86 \\
Dec & 4.39 & 2.421 & 2.715 & 5.705 & 3.569 & 4.119 & 5.186 & 3.708 & 2.715 & 3.569 & 3.983 & 3.004 \\
Aver & 4.172 & 2.33 & 2.687 & 4.978 & 4.033 & 4.236 & 4.98 & 3.746 & 3.145 & 3.31 & 3.589 & 2.882 \\
\hline
\end{tabular}

\begin{tabular}{lllllllllllll}
\hline Mois & Abec & Am-T & Bok & Fay & Mon & Mou & N'Dja & Pala & Sarh & Bol & Mao & Ati \\
\hline Jan & 4.622 & 2.833 & 3.144 & 6.411 & 3.897 & 5.185 & 5.873 & 4.479 & 3.449 & 3.897 & 4.19 & 3.144 \\
Feb & 4.764 & 2.99 & 3.449 & 6.143 & 4.622 & 5.462 & 6.411 & 4.905 & 3.897 & 3.897 & 4.335 & 3.449 \\
Mar & 5.185 & 2.675 & 3.449 & 6.008 & 5.185 & 5.185 & 6.677 & 4.905 & 4.19 & 3.897 & 4.479 & 3.6 \\
Apr & 5.046 & 2.833 & 3.144 & 5.462 & 5.185 & 5.462 & 5.324 & 4.764 & 5.324 & 3.6 & 3.897 & 3.298 \\
May & 4.622 & 3.144 & 3.144 & 4.905 & 5.185 & 4.905 & 5.324 & 4.622 & 4.044 & 3.449 & 3.749 & 3.298 \\
Jun & 4.19 & 2.833 & 3.144 & 4.622 & 4.905 & 4.764 & 5.873 & 4.19 & 3.6 & 3.6 & 3.749 & 3.298 \\
Jul & 4.479 & 2.515 & 2.99 & 4.044 & 4.335 & 4.622 & 5.324 & 3.749 & 3.144 & 3.897 & 3.749 & 3.298 \\
Aug & 3.749 & 2.021 & 2.515 & 3.897 & 3.749 & 4.044 & 4.335 & 3.144 & 2.675 & 3.298 & 3.298 & 2.675 \\
Sept & 3.6 & 2.021 & 2.353 & 5.046 & 3.298 & 3.749 & 4.19 & 3.144 & 2.675 & 2.833 & 3.298 & 2.675 \\
Oct & 4.479 & 2.021 & 2.353 & 5.6 & 4.044 & 3.6 & 4.19 & 3.449 & 2.675 & 3.298 & 3.749 & 2.833 \\
Nov & 4.905 & 2.353 & 2.833 & 6.277 & 4.335 & 3.749 & 5.462 & 3.6 & 2.675 & 3.897 & 4.19 & 3.144 \\
Dec & 4.764 & 2.675 & 2.99 & 6.143 & 3.897 & 4.479 & 5.6 & 4.044 & 2.99 & 3.897 & 4.335 & 3.298 \\
Aver & 4.534 & 2.576 & 2.959 & 5.38 & 4.386 & 4.601 & 5.382 & 4.083 & 3.445 & 3.622 & 3.918 & 3.167 \\
\hline
\end{tabular}


Table 9 Extrapolation of the parameter $k$ to $30 \mathrm{~m}$

\begin{tabular}{lllllllllllll}
\hline Mois & Abec & Am-T & Bok & Fay & Mon & Mou & N'Dja & Pala & Sarh & Bol & Mao & Ati \\
\hline Jan & 3.081 & 1.105 & 3.878 & 3.82 & 3.848 & 3.648 & 4.666 & 3.224 & 1.206 & 4.916 & 4.35 & 2.899 \\
Feb & 3.547 & 1.072 & 3.436 & 3.715 & 3.516 & 3.274 & 4.243 & 3.574 & 1.244 & 4.565 & 4.476 & 2.835 \\
Mar & 3.218 & 4.588 & 4.126 & 3.041 & 3.871 & 3.288 & 4.514 & 3.174 & 1.32 & 4.7 & 4.812 & 2.911 \\
Apr & 3.582 & 4.474 & 4.336 & 3.958 & 3.576 & 2.904 & 3.964 & 3.236 & 1.637 & 4.16 & 4.632 & 2.647 \\
May & 3.081 & 1.542 & 3.878 & 3.664 & 3.108 & 3.058 & 4.352 & 3.516 & 3.429 & 4.3 & 4.955 & 2.723 \\
Jun & 3.113 & 2.151 & 3.983 & 3.811 & 3.121 & 3.175 & 4.729 & 3.309 & 3.767 & 4.471 & 4.407 & 2.723 \\
Jul & 3.149 & 2.478 & 3.51 & 3.67 & 2.96 & 3.338 & 4.411 & 4.022 & 3.778 & 4.632 & 4.551 & 2.895 \\
Aug & 2.816 & 3.598 & 3.304 & 3.589 & 2.901 & 2.731 & 4.121 & 3.594 & 3.175 & 4.203 & 4.911 & 3.175 \\
Sept & 2.813 & 3.214 & 3.792 & 3.598 & 2.684 & 3.088 & 4.133 & 3.138 & 3.175 & 3.949 & 5.199 & 3.175 \\
Oct & 3.324 & 2.465 & 3.532 & 4.08 & 3.397 & 2.42 & 3.563 & 3.682 & 2.953 & 4.65 & 4.785 & 2.642 \\
Nov & 3.797 & 1.213 & 3.949 & 4.231 & 3.668 & 3.267 & 4.45 & 2.666 & 1.694 & 4.502 & 4.133 & 2.198 \\
Dec & 3.625 & 1.187 & 3.84 & 4.222 & 3.294 & 3.388 & 4.137 & 2.285 & 1.307 & 4.204 & 4.796 & 2.806 \\
Aver & 3.262 & 2.424 & 3.797 & 3.783 & 3.329 & 3.132 & 4.274 & 3.285 & 2.39 & 4.438 & 4.667 & 2.802 \\
\hline
\end{tabular}

value of 1.072 is recorded in February in Am-Timan, while the highest value of 5.199 is recorded in Mao in the month of September.

Table 10 presents values of $k$ at altitude of $50 \mathrm{~m}$. From Table 10, it can be seen that at $50 \mathrm{~m}$ altitude the minimum $k$ value of 1.077 is recorded at Am-Timan in February and the maximum value of 5.223 at Mao is recorded in September.

Table 11 presents extrapolated values of parameter $k$ at $67 \mathrm{~m}$ altitude. The least value of 1.08 is observed in AmTiman in February, while the highest value of 5.237 is recorded in Mao in September.

Table 12 presents extrapolated values of the scale parameter $c$ at $30 \mathrm{~m}$ altitude. From Table 12, it can be seen that the minimum value of $1.65 \mathrm{~m} / \mathrm{s}$ is recorded in the month of August in Am-Timan, while the maximum value of $5.964 \mathrm{~m} / \mathrm{s}$ is recorded in N'Djamena in the month of March.

Table 13 presents extrapolated values of parameter $c$ at $50 \mathrm{~m}$ altitude. From Table 13, it can be seen that the minimum value of parameter $c$ is $1.984 \mathrm{~m} / \mathrm{s}$ in the month of August in Am-Timan, while the maximum value of $6.727 \mathrm{~m} / \mathrm{s}$ is recorded in N'Djamena in the month of March.

The extrapolated values of parameter $c$ extrapolated at $67 \mathrm{~m}$ altitude are presented in Table 14. From Table 14, the minimum value of $2.205 \mathrm{~m} / \mathrm{s}$ is recorded in Am-Timan in August, while the maximum value of $7.208 \mathrm{~m} / \mathrm{s}$ is recorded in N'Djamena in March. It is found that the value of $c$ increases with altitude, and hence, it can be concluded that the site assessed is windy.

\section{Comparison of the wind energy potential at the three climatic zones assessed}

From the comparison of wind characteristics in the three selected climatic zones at $10 \mathrm{~m}$ altitude, it can be deduced that:

The minimum wind speed of $1.342 \mathrm{~m} / \mathrm{s}$ is recorded at AmTiman, while the maximum speed of $3.25 \mathrm{~m} / \mathrm{s}$ is recorded at N'Djamena and Faya-Largeau.
Table 10 Extrapolation of the parameter $k$ to $50 \mathrm{~m}$

\begin{tabular}{lllllllllllll}
\hline Mois & Abec & Am-T & Bok & Fay & Mon & Mou & N'Dja & Pala & Sarh & Bol & Mao & Ati \\
\hline Jan & 3.095 & 1.11 & 3.895 & 3.837 & 3.866 & 3.665 & 4.688 & 3.239 & 1.211 & 4.938 & 4.37 & 2.912 \\
Feb & 3.564 & 1.077 & 3.452 & 3.732 & 3.532 & 3.289 & 4.262 & 3.59 & 1.25 & 4.586 & 4.497 & 2.848 \\
Mar & 3.233 & 4.609 & 4.145 & 3.055 & 3.888 & 3.303 & 4.534 & 3.188 & 1.326 & 4.721 & 4.834 & 2.925 \\
Apr & 3.598 & 4.495 & 4.356 & 3.976 & 3.592 & 2.917 & 3.983 & 3.251 & 1.644 & 4.179 & 4.653 & 2.659 \\
May & 3.095 & 1.549 & 3.895 & 3.68 & 3.122 & 3.072 & 4.372 & 3.532 & 3.445 & 4.319 & 4.978 & 2.736 \\
Jun & 3.127 & 2.161 & 4.001 & 3.828 & 3.136 & 3.189 & 4.75 & 3.324 & 3.784 & 4.492 & 4.427 & 2.736 \\
Jul & 3.163 & 2.489 & 3.526 & 3.686 & 2.973 & 3.354 & 4.431 & 4.04 & 3.795 & 4.653 & 4.572 & 2.908 \\
Aug & 2.829 & 3.614 & 3.319 & 3.605 & 2.914 & 2.744 & 4.14 & 3.61 & 3.189 & 4.222 & 4.933 & 3.189 \\
Sept & 2.826 & 3.229 & 3.809 & 3.614 & 2.696 & 3.102 & 4.152 & 3.153 & 3.189 & 3.967 & 5.223 & 3.189 \\
Oct & 3.339 & 2.476 & 3.548 & 4.098 & 3.412 & 2.432 & 3.579 & 3.698 & 2.966 & 4.671 & 4.807 & 2.654 \\
Nov & 3.814 & 1.218 & 3.967 & 4.25 & 3.684 & 3.282 & 4.47 & 2.678 & 1.702 & 4.522 & 4.152 & 2.208 \\
Dec & 3.642 & 1.192 & 3.858 & 4.241 & 3.309 & 3.403 & 4.156 & 2.296 & 1.313 & 4.223 & 4.818 & 2.819 \\
Aver & 3.277 & 2.435 & 3.814 & 3.8 & 3.344 & 3.146 & 4.293 & 3.3 & 2.401 & 4.458 & 4.689 & 2.815 \\
\hline
\end{tabular}


Table 11 Extrapolation of the parameter $k$ to $67 \mathrm{~m}$

\begin{tabular}{lllllllllllll}
\hline Months & Abec & Am-T & Bok & Fay & Mon & Mou & N'Dja & Pala & Sarh & Bol & Mao & Ati \\
\hline Jan & 3.103 & 1.113 & 3.905 & 3.848 & 3.876 & 3.675 & 4.7 & 3.247 & 1.214 & 4.951 & 4.381 & 2.92 \\
Fév & 3.573 & 1.08 & 3.461 & 3.742 & 3.541 & 3.297 & 4.274 & 3.599 & 1.253 & 4.598 & 4.509 & 2.856 \\
Mar & 3.241 & 4.621 & 4.156 & 3.063 & 3.898 & 3.312 & 4.546 & 3.197 & 1.329 & 4.733 & 4.846 & 2.932 \\
Apr & 3.608 & 4.507 & 4.367 & 3.987 & 3.601 & 2.925 & 3.993 & 3.26 & 1.649 & 4.19 & 4.665 & 2.666 \\
May & 3.103 & 1.553 & 3.905 & 3.69 & 3.131 & 3.08 & 4.384 & 3.541 & 3.454 & 4.331 & 4.991 & 2.743 \\
Jun & 3.136 & 2.166 & 4.011 & 3.838 & 3.144 & 3.198 & 4.763 & 3.333 & 3.794 & 4.504 & 4.438 & 2.743 \\
Jul & 3.171 & 2.496 & 3.535 & 3.696 & 2.981 & 3.362 & 4.442 & 4.051 & 3.805 & 4.665 & 4.584 & 2.916 \\
Aug & 2.837 & 3.624 & 3.328 & 3.615 & 2.922 & 2.751 & 4.151 & 3.62 & 3.198 & 4.233 & 4.946 & 3.198 \\
Sept & 2.834 & 3.237 & 3.819 & 3.624 & 2.703 & 3.11 & 4.163 & 3.161 & 3.198 & 3.978 & 5.237 & 3.198 \\
Oct & 3.348 & 2.483 & 3.558 & 4.109 & 3.421 & 2.438 & 3.588 & 3.708 & 2.974 & 4.684 & 4.82 & 2.661 \\
Nov & 3.824 & 1.222 & 3.978 & 4.261 & 3.694 & 3.29 & 4.482 & 2.685 & 1.707 & 4.534 & 4.163 & 2.214 \\
Dec & 3.651 & 1.195 & 3.868 & 4.252 & 3.318 & 3.412 & 4.167 & 2.302 & 1.316 & 4.234 & 4.831 & 2.826 \\
Aver & 3.286 & 2.441 & 3.824 & 3.81 & 3.353 & 3.154 & 4.304 & 3.309 & 2.407 & 4.47 & 4.701 & 2.823 \\
\hline
\end{tabular}

Table 12 Extrapolation of parameter $c$ at $30 \mathrm{~m}$ altitude
Table 13 Extrapolation of parameter $c$ to $50 \mathrm{~m}$

\begin{tabular}{lllllllllllll}
\hline Months & Abec & Am-T & Bok & Fay & Mon & Mou & N'Dja & Pala & Sarh & Bol & Mao & Ati \\
\hline Jan & 4.076 & 2.232 & 2.656 & 5.756 & 3.354 & 4.583 & 5.179 & 3.932 & 2.83 & 3.311 & 3.604 & 2.69 \\
Feb & 4.186 & 2.345 & 2.954 & 5.504 & 4.052 & 4.874 & 5.725 & 4.319 & 3.253 & 3.324 & 3.735 & 2.977 \\
Mar & 4.609 & 2.209 & 2.926 & 5.421 & 4.569 & 4.605 & 5.964 & 4.342 & 3.561 & 3.319 & 3.854 & 3.115 \\
Apr & 4.454 & 2.354 & 2.64 & 4.83 & 4.587 & 4.898 & 4.697 & 4.204 & 4.744 & 3.065 & 3.321 & 2.841 \\
May & 4.076 & 2.665 & 2.656 & 4.315 & 4.616 & 4.35 & 4.674 & 4.052 & 3.51 & 2.921 & 3.173 & 2.839 \\
Jun & 3.663 & 2.416 & 2.652 & 4.036 & 4.346 & 4.207 & 5.176 & 3.653 & 3.08 & 3.052 & 3.193 & 2.839 \\
Jul & 3.936 & 2.121 & 2.527 & 3.499 & 3.808 & 4.062 & 4.67 & 3.208 & 2.658 & 3.321 & 3.188 & 2.833 \\
Aug & 3.259 & 1.65 & 2.1 & 3.365 & 3.256 & 3.542 & 3.751 & 2.666 & 2.249 & 2.784 & 2.761 & 2.249 \\
Sept & 3.119 & 1.659 & 1.94 & 4.452 & 2.84 & 3.248 & 3.614 & 2.681 & 2.249 & 2.37 & 2.754 & 2.249 \\
Oct & 3.926 & 1.674 & 1.948 & 4.954 & 3.511 & 3.131 & 3.641 & 2.944 & 2.256 & 2.77 & 3.179 & 2.41 \\
Nov & 4.306 & 1.871 & 2.37 & 5.597 & 3.773 & 3.24 & 4.8 & 3.124 & 2.253 & 3.326 & 3.614 & 2.706 \\
Dec & 4.181 & 2.14 & 2.515 & 5.467 & 3.378 & 3.924 & 4.951 & 3.555 & 2.465 & 3.337 & 3.721 & 2.836 \\
Aver & 3.983 & 2.111 & 2.49 & 4.766 & 3.841 & 4.055 & 4.737 & 3.557 & 2.926 & 3.075 & 3.341 & 2.715 \\
\hline
\end{tabular}

\begin{tabular}{lllllllllllll}
\hline Months & Abec & Am-T & Bok & Fay & Mon & Mou & N'Dja & Pala & Sarh & Bol & Mao & Ati \\
\hline Jan & 4.686 & 2.644 & 3.119 & 6.503 & 3.892 & 5.237 & 5.883 & 4.528 & 3.313 & 3.846 & 4.168 & 3.157 \\
Feb & 4.805 & 2.771 & 3.45 & 6.233 & 4.659 & 5.553 & 6.471 & 4.951 & 3.781 & 3.86 & 4.312 & 3.476 \\
Mar & 5.266 & 2.618 & 3.42 & 6.144 & 5.223 & 5.262 & 6.727 & 4.976 & 4.121 & 3.854 & 4.442 & 3.629 \\
Apr & 5.097 & 2.781 & 3.101 & 5.505 & 5.242 & 5.579 & 5.361 & 4.825 & 5.412 & 3.573 & 3.857 & 3.325 \\
May & 4.686 & 3.129 & 3.119 & 4.945 & 5.273 & 4.984 & 5.336 & 4.659 & 4.065 & 3.414 & 3.693 & 3.323 \\
Jun & 4.233 & 2.85 & 3.114 & 4.642 & 4.98 & 4.828 & 5.879 & 4.222 & 3.59 & 3.559 & 3.715 & 3.323 \\
Jul & 4.532 & 2.519 & 2.974 & 4.053 & 4.393 & 4.67 & 5.332 & 3.731 & 3.121 & 3.857 & 3.709 & 3.315 \\
Aug & 3.788 & 1.984 & 2.495 & 3.905 & 3.785 & 4.1 & 4.329 & 3.13 & 2.663 & 3.262 & 3.236 & 2.663 \\
Sept & 3.633 & 1.995 & 2.314 & 5.095 & 3.324 & 3.776 & 4.179 & 3.147 & 2.663 & 2.798 & 3.228 & 2.663 \\
Oct & 4.521 & 2.012 & 2.323 & 5.64 & 4.066 & 3.647 & 4.209 & 3.439 & 2.67 & 3.246 & 3.7 & 2.843 \\
Nov & 4.936 & 2.236 & 2.798 & 6.333 & 4.353 & 3.767 & 5.473 & 3.639 & 2.667 & 3.862 & 4.179 & 3.174 \\
Dec & 4.8 & 2.54 & 2.961 & 6.193 & 3.92 & 4.519 & 5.636 & 4.114 & 2.905 & 3.875 & 4.297 & 3.32 \\
Aver & 4.582 & 2.506 & 2.932 & 5.432 & 4.426 & 4.66 & 5.401 & 4.113 & 3.414 & 3.584 & 3.878 & 3.184 \\
\hline
\end{tabular}


Table 14 Extrapolation of parameter $c$ to $67 \mathrm{~m}$

\begin{tabular}{lllllllllllll}
\hline Months & Abec & Am-T & Bok & Fay & Mon & Mou & N'Dja & Pala & Sarh & Bol & Mao & Ati \\
\hline Jan & 5.075 & 2.913 & 3.419 & 6.975 & 4.239 & 5.653 & 6.328 & 4.909 & 3.625 & 4.19 & 4.53 & 3.46 \\
Feb & 5.201 & 3.049 & 3.771 & 6.693 & 5.047 & 5.984 & 6.941 & 5.353 & 4.122 & 4.205 & 4.682 & 3.798 \\
Mar & 5.683 & 2.885 & 3.739 & 6.6 & 5.638 & 5.679 & 7.208 & 5.379 & 4.48 & 4.199 & 4.819 & 3.961 \\
Apr & 5.506 & 3.059 & 3.401 & 5.934 & 5.659 & 6.011 & 5.783 & 5.221 & 5.836 & 3.902 & 4.202 & 3.639 \\
May & 5.075 & 3.43 & 3.419 & 5.348 & 5.691 & 5.388 & 5.757 & 5.047 & 4.421 & 3.733 & 4.028 & 3.636 \\
Jun & 4.599 & 3.134 & 3.415 & 5.029 & 5.384 & 5.224 & 6.324 & 4.588 & 3.919 & 3.887 & 4.052 & 3.636 \\
Jul & 4.914 & 2.78 & 3.266 & 4.408 & 4.767 & 5.058 & 5.753 & 4.069 & 3.422 & 4.202 & 4.046 & 3.628 \\
Aug & 4.129 & 2.205 & 2.754 & 4.252 & 4.126 & 4.459 & 4.7 & 3.431 & 2.933 & 3.571 & 3.544 & 2.933 \\
Sept & 3.965 & 2.216 & 2.56 & 5.505 & 3.637 & 4.116 & 4.542 & 3.449 & 2.933 & 3.078 & 3.535 & 2.933 \\
Oct & 4.902 & 2.235 & 2.57 & 6.074 & 4.423 & 3.98 & 4.573 & 3.76 & 2.941 & 3.555 & 4.035 & 3.126 \\
Nov & 5.338 & 2.476 & 3.078 & 6.797 & 4.726 & 4.107 & 5.9 & 3.971 & 2.938 & 4.208 & 4.542 & 3.478 \\
Dec & 5.195 & 2.802 & 3.252 & 6.652 & 4.268 & 4.9 & 6.07 & 4.473 & 3.192 & 4.221 & 4.666 & 3.633 \\
Aver & 4.965 & 2.765 & 3.22 & 5.856 & 4.8 & 5.047 & 5.823 & 4.471 & 3.73 & 3.912 & 4.223 & 3.488 \\
\hline
\end{tabular}

Table 15 Characteristics of selected wind turbines

\begin{tabular}{lllc}
\hline Characteristics & $\begin{array}{l}\text { Bonus } \\
300 \mathrm{~kW} / 33\end{array}$ & $\begin{array}{l}\text { AN Bonus } \\
1 \mathrm{MW} / 54\end{array}$ & Vestas 2 MW/80 \\
\hline Rated power $P_{\mathrm{r}}(\mathrm{kW})$ & 300 & 1000 & 2000 \\
Hub height $h(\mathrm{~m})$ & 30 & 50 & 67 \\
Rotor diameter $(\mathrm{m})$ & 33.4 & 54.2 & 80 \\
$\begin{array}{l}\text { Rated wind speed } V_{\mathrm{r}} \\
\quad(\mathrm{m} / \mathrm{s})\end{array}$ & 14 & 15 & 16 \\
$\begin{array}{l}\text { Cut-in wind speed } V_{\mathrm{c}} \\
(\mathrm{m} / \mathrm{s})\end{array}$ & 3 & 3 & 4 \\
$\begin{array}{l}\text { Cut-off wind speed } V_{\mathrm{f}} \\
(\mathrm{m} / \mathrm{s})\end{array}$ & 25 & 25 & 25 \\
\hline
\end{tabular}

As for the power density, the highest power density of $28,609 \mathrm{~W} / \mathrm{m}^{2}$ is recorded at Faya-Largeau and the least power density of $3163 \mathrm{~W} / \mathrm{m}^{2}$ is recorded at Bokoro.

\section{Estimation of electric power generation by wind turbines}

Three wind turbines were selected for the estimation of wind power generation: Bonus $300 \mathrm{~kW} / 33$, Bonus $1 \mathrm{MW} / 54$, and Vestas $2 \mathrm{MW} / \mathrm{V} 80$. Their rated power (Pr) is 300,1000 , and $2000 \mathrm{~kW}$, respectively.

Table 15 shows the characteristic properties of selected wind turbines (Bonus $300 \mathrm{~kW} / 33$, Bonus $1 \mathrm{MW} / 54$ and Vestas $2 \mathrm{MW} / 80$ ).

For the three wind turbines, the one whose power is high is Vestas $2 \mathrm{MW} / \mathrm{V} 80$ including Faya-Largeau $(327.18 \mathrm{~kW})$ and Bokoro $(9.49 \mathrm{~kW})$. The wind turbine with the lowest power is Bonus $300 \mathrm{~kW} / 33$, Faya-Largeau $(61.53 \mathrm{~kW})$, and Bokoro (1.19 kW).
Table 16 Calculated annual energy estimate for selected wind turbines for selected sites

\begin{tabular}{|c|c|c|c|c|c|c|c|c|c|}
\hline \multirow[t]{2}{*}{ Sites } & \multicolumn{3}{|c|}{ BONUS $300 \mathrm{~kW} / 33$} & \multicolumn{3}{|c|}{ BONUS $1 \mathrm{MW} / 54$} & \multicolumn{3}{|c|}{ VESTAS 2 MW/V80 } \\
\hline & $P_{\mathrm{e}, \mathrm{m}}$ & $C_{\mathrm{f}}(\%)$ & $E_{\text {out }}$ & $P_{\mathrm{e}, \mathrm{m}}$ & $C_{\mathrm{f}}(\%)$ & $E_{\text {out }}$ & $P_{\mathrm{e}, \mathrm{m}}$ & $C_{\mathrm{f}}(\%)$ & $E_{\text {out }}$ \\
\hline beche & 7.52 & 2.51 & 5418 & 197.43 & 19.74 & 142,148 & 327.18 & 16.36 & 235,569 \\
\hline Am-Timan & 50.18 & 16.73 & 36,132 & 240.28 & 24.03 & 173,003 & 382.92 & 19.15 & 275,703 \\
\hline Bokoro & 1.19 & 0.4 & 855 & 10.49 & 1.05 & 7554 & 9.49 & 0.47 & 6830 \\
\hline Mongo & 36.02 & 12.01 & 25,935 & 172.26 & 17.23 & 124,026 & 283.76 & 14.19 & 204,304 \\
\hline N’Djamena & 34.18 & 11.39 & 24,609 & 152.89 & 15.29 & 110,080 & 283.31 & 14.17 & 203,984 \\
\hline Faya-Larg & 61.53 & 20.51 & 44,301 & 266.06 & 26.61 & 191,564 & 488.34 & 24.42 & 351,603 \\
\hline Moundou & 56.07 & 18.69 & 40,373 & 257.30 & 25.73 & 185,257 & 435.46 & 21.77 & 313,533 \\
\hline Pala & 31.78 & 10.59 & 22,879 & 154.81 & 15.48 & 111,464 & 247.86 & 12.39 & 178,457 \\
\hline Sarh & 115.50 & 38.5 & 83,159 & 493.72 & 49.37 & 355,477 & 840.42 & 42.02 & 605,101 \\
\hline Bol & 1.99 & 0.66 & 1435 & 13.79 & 1.38 & 9925 & 16.84 & 0.84 & 12,124 \\
\hline Mao & 3.42 & 1.14 & 2461 & 20.03 & 2.00 & 14,423 & 29.39 & 1.47 & 21,162 \\
\hline Ati & 12.45 & 4.15 & 8964 & 77.93 & 7.79 & 56,109 & 96.59 & 4.83 & 69,548 \\
\hline
\end{tabular}




\section{Annual energy generated by the three turbines for the 12 selected locations in Chad}

Table 16 shows the annual energy generated by wind turbines selected for this study. It can be seen from Table 16 that:

- Bonus $300 \mathrm{~kW} / 33$ has the lowest capacity factor of $0.4 \%$ recorded in Bokoro and the highest capacity factor of $38.5 \%$ in Sarh.

- Bonus $1 \mathrm{MW} / 54$ has the least capacity factor of $1.05 \%$ in Bokoro and the highest capacity factor of $49.37 \%$ in Sarh.

- $2 \mathrm{MW} / \mathrm{V} 80$ Bonus has the least capacity factor of $0.47 \%$ in Bokoro and highest capacity factor of $42.02 \%$ in Sarh.

In addition, Vestas $2 \mathrm{MW} / \mathrm{V} 80$ wind turbine produces highest energy output of $601.10 \mathrm{MWh} /$ year and capacity factor of $42.02 \%$ in Sarh. According to [1], the value of this factor is generally affected by the intermittent nature of the wind, the availability of the machine and the efficiency of the turbine. Capacity factor usually varies from 20 to $70 \%$ in practice.

Where $P_{\mathrm{e}, \mathrm{m}}(\mathrm{kW} / \mathrm{year})$ is the annual power produced by the turbine, $C_{\mathrm{f}}(\%)$ is the capacity factor of the wind turbine, and $E_{\text {out }}(\mathrm{MWh} /$ year) is the annual production of accumulated energy.

\section{Cost of electrical energy generated by the wind energy}

Costs per kilowatt-hour ( $\mathrm{kWh})$ of electrical energy generated by the three wind turbines at 12 selected sites. This calculation was performed for the maximum and minimum values of thes specific cost of wind turbines (Tables 17, 18, 19).

The results obtained are shown in Table 17 which shows that the lowest value of the cost of wind power varies from $\$ 143.08 / \mathrm{kWh} /$ year to $\$ 132,343.89 / \mathrm{kWh} /$ year. This value was obtained for the Vestas $2 \mathrm{MW} / \mathrm{V} 80$ wind turbine.
Table 17 Cost of electrical energy generated by Bonus $300 \mathrm{~kW} / 33$ wind turbine
Table 18 Cost of electrical energy generated by BONUS $1 \mathrm{MW} / 54$ wind turbine

\begin{tabular}{lcccccr}
\hline Locations & $P_{\text {out }}$ & $P_{\text {er }}$ & $C_{\mathrm{f}}(\%)$ & \multicolumn{1}{c}{$E_{\mathrm{WT}}$} & \multicolumn{1}{c}{$C_{\mathrm{USS}}$} & \multicolumn{1}{c}{$C_{\mathrm{XAF}}$} \\
\hline Abeche & 7.52 & 300 & 2.51 & $82,391.09$ & 960.59 & 5801.97 \\
Am-Timan & 50.18 & 300 & 16.73 & $549,504.95$ & $215,527.37$ & $1,301,785.29$ \\
Bokoro & 1.19 & 300 & 0.4 & $13,002.03$ & $73,249.9$ & $442,429.41$ \\
Faya & 61.53 & 300 & 20.51 & $673,753.5$ & 193.91 & 1171.2 \\
Mongo & 36.02 & 300 & 12.01 & $394,426.67$ & 281.27 & 1698.88 \\
Moundou & 56.07 & 300 & 18.69 & $614,002.64$ & 168.23 & 1016.13 \\
N'Djamena & 34.18 & 300 & 11.39 & $374,250.2$ & 281.79 & 1702.02 \\
Pala & 31.78 & 300 & 10.59 & $347,950.49$ & 742.03 & 4481.88 \\
Sarh & 115.5 & 300 & 38.5 & $1,264,705.29$ & 2083.28 & $12,583.03$ \\
Bol & 1.99 & 300 & 0.66 & $21,818.97$ & 6044.97 & $36,511.62$ \\
Mao & 3.42 & 300 & 1.14 & $37,432.58$ & 7313.61 & $44,174.2$ \\
Ati & 12.45 & 300 & 4.15 & $136,324.22$ & 1635.68 & 9879.49 \\
\hline
\end{tabular}

\begin{tabular}{lccclll}
\hline Locations & $P_{\text {out }}$ & $P_{\text {er }}$ & $C_{\mathrm{f}}(\%)$ & $E_{\mathrm{WT}}$ & $C_{\mathrm{USS}}$ & $C_{\mathrm{XAF}}$ \\
\hline Abeche & 197.43 & 1000 & 19.74 & $2,161,858.5$ & 118.22 & 714.05 \\
Am-Timan & 240.28 & 1000 & 24.03 & $2,631,109.8$ & $27,527.15$ & 166,264 \\
Bokoro & 10.49 & 1000 & 1.05 & $114,876.45$ & 6226.88 & $37,610.3$ \\
Faya & 266.06 & 1000 & 26.61 & $2,913,378.9$ & 130.13 & 785.98 \\
Mongo & 172.26 & 1000 & 17.23 & $1,886,247$ & 174.7 & 1055.2 \\
Moundou & 257.3 & 1000 & 25.73 & $2,817,435$ & 110.45 & 667.15 \\
N'Djamena & 152.89 & 1000 & 15.29 & $1,674,101.7$ & 191.6 & 1157.24 \\
Pala & 154.81 & 1000 & 15.48 & $1,695,191.4$ & 349.21 & 2109.21 \\
Sarh & 493.72 & 1000 & 49.37 & $5,406,234$ & 649.77 & 3924.59 \\
Bol & 13.78 & 1000 & 1.38 & $150,934.8$ & 2081.97 & $12,575.1$ \\
Mao & 20.03 & 1000 & 2.00 & $219,361.35$ & 2510.57 & $15,163.8$ \\
Ati & 77.93 & 1000 & 7.79 & $853,333.5$ & 539.67 & 3259.62 \\
\hline
\end{tabular}


Table 19 Cost of electrical energy generated by VESTAS $2 \mathrm{MW} / \mathrm{V} 80$ wind turbine

\begin{tabular}{lrlrrrr}
\hline Locations & \multicolumn{1}{c}{$P_{\text {out }}$} & $P_{\text {er }}$ & $C_{\mathrm{f}}(\%)$ & \multicolumn{1}{c}{$E_{\mathrm{WT}}$} & \multicolumn{1}{c}{$C_{\mathrm{USS}}$} & \multicolumn{1}{c}{$C_{\mathrm{XAF}}$} \\
\hline Abeche & 327.18 & 2000 & 16.36 & $3,582,621$ & 147.39 & 890.25 \\
Am-Timan & 382.92 & 2000 & 19.15 & $4,192,996$ & $132,343.89$ & $799,357.1$ \\
Bokoro & 9.49 & 2000 & 0.47 & 103,916 & $56,876.63$ & $343,534.87$ \\
Faya & 488.34 & 2000 & 24.42 & $5,347,279$ & 159.67 & 964.4 \\
Mongo & 283.75 & 2000 & 14.19 & $3,107,150$ & 234.9 & 1418.8 \\
Moundou & 435.46 & 2000 & 21.77 & $4,768,309$ & 143.08 & 864.21 \\
N'Djaména & 283.31 & 2000 & 14.17 & $3,102,266$ & 224.59 & 1356.5 \\
Pala & 247.86 & 2000 & 12.39 & $2,714,045$ & 619.44 & 3741.39 \\
Sarh & 840.42 & 2000 & 42.02 & $9,202,555$ & 1733.31 & $10,469.17$ \\
Bol & 16.84 & 2000 & 0.84 & $1,84,420$ & 4935.24 & $29,808.88$ \\
Mao & 29.39 & 2000 & 1.47 & $3,21,821$ & 5896.99 & $35,617.82$ \\
Ati & 96.59 & 2000 & 4.83 & $1,057,661$ & 1369.09 & 8269.3 \\
\hline
\end{tabular}

\section{Conclusion}

In this study, comprehensive estimation of the electrical energy generated and cost per kilowatt-hour of electrical energy generated by three different types of wind turbines at selected locations in Chad are carried out. The results obtained showed that:

- The average annual speed varies from $1 \mathrm{~m} / \mathrm{s}$ in AmTiman to $4.2 \mathrm{~m} / \mathrm{s}$ in N'Djamena at $10 \mathrm{~m}$ high. The maximum wind speed occurs in the month of March, while the least speed occurs in the months of August, September, and October.

- The wind speed is extrapolated to 30.50 and $67 \mathrm{~m}$ altitude. Similarly, Weibull parameters $k$ and $c$ are also extrapolated to 30.50 and $67 \mathrm{~m}$ altitude.

- The capacity factor values vary from one wind turbine to another: for the $300 \mathrm{~kW} / 33$ Bonus wind turbine, it varies from 0.4 to $38.5 \%$. For Bonus $1 \mathrm{MW} / 54$, the value varies between 1.05 and $49.37 \%$ and Vestas $2 \mathrm{MW} / \mathrm{V} 80$, it is from 0.47 to $42.02 \%$.

- Comparative assessment of electricity generated by the three types of wind turbines was carried out. Result of this study shows that Vestas $2 \mathrm{MW} / \mathrm{V} 80$ wind turbine with a hub height of $80 \mathrm{~m}$ produced the highest energy.

- For the Sarh site, the highest capacity factor, annual power, and energy output are $42.02 \%, 840.42 \mathrm{~kW} /$ year, and $605.10 \mathrm{MWh} /$ year, respectively, recorded. The least capacity factor, annual power, and energy output of $0.47 \%, 9.49 \mathrm{~kW} / \mathrm{year}$, and $6830 \mathrm{MWh}$, respectively are recorded in Bokoro.

- The average least cost per kWh of electricity generated was obtained at Moundou of $143.08 \$ / \mathrm{kWh} /$ year the model Vestas $2 \mathrm{MW} / \mathrm{V} 80$, while the highest average cost of $\$ 132,343.89 / \mathrm{kWh} /$ year recorded in Am-Timan. Based on these values, it can be concluded that for the
Am-Timan site, wind power generation, with wind turbines, is not economical.

- For the three wind turbines, the one whose power is high is Vestas 2 MW/V80 including Faya-Largeau $(327.18 \mathrm{~kW})$ and Bokoro $(9.49 \mathrm{~kW})$. The wind turbine with the lowest power is Bonus $300 \mathrm{~kW} / 33$, FayaLargeau $(61.53 \mathrm{~kW})$, and Bokoro $(1.19 \mathrm{~kW})$.

- Electrical and mechanical applications not connected to the network (water pumping, recharging of batteries) would be more suitable. On the other hand, the construction of a wind farm in the Moundou region can be considered.

Acknowledgements We make a point of thanking the persons in charge of the National Meteorology for Chad, as the personnel who deal with the collection and the processing weather data on these sites, to have placed at our disposal the data which were used in our work.

\section{Compliance with ethical standards}

Conflict of interest The authors declare that there is no conflict of interests regarding the publication of this paper.

Open Access This article is licensed under a Creative Commons Attribution 4.0 International License, which permits use, sharing, adaptation, distribution and reproduction in any medium or format, as long as you give appropriate credit to the original author(s) and the source, provide a link to the Creative Commons licence, and indicate if changes were made. The images or other third party material in this article are included in the article's Creative Commons licence, unless indicated otherwise in a credit line to the material. If material is not included in the article's Creative Commons licence and your intended use is not permitted by statutory regulation or exceeds the permitted use, you will need to obtain permission directly from the copyright holder. To view a copy of this licence, visit http://creativecommons.org/licenses/by/4.0/. 


\section{References}

1. Belabes, B., Youce, A., Guerri, O., Djamai, M., Kaabeche, A.: Evaluation of wind energy potential and estimation of cost using wind energy turbines for electricity generation in north of Algeria. Renew. Sustain. Energy Rev. 51, 1245-1255 (2015)

2. Stambouli, A.B., Khiat, Z., Flazi, S., Kitamura, Y.: A review on the renewable energy development in Algeria current perspective, energy scenario and sustainability issues. Renew. Sustain. Energy Rev. 16, 4445-4460 (2012)

3. Gökçek, M., Mustafa, S.G.: Evaluation of electricity generation and energy cost of wind energy conversion systems (WECSs) in Central Turkey. Appl. Energy 86, 2731-2739 (2009)

4. Ohunakin, S.: Energy utilization and renewable energy sources in Nigeria. J. Eng. Appl. Sci. 5, 171-177 (2010)

5. Ucar, A., Balo, F.: A seasonal analysis of wind turbine characteristics and wind power potential in Manisa, Turkey. Int. J. Green Energy 5, 466-479 (2008)

6. Yaniktepe, B., Koroglu, T., Savrun, M.M.: Investigation of wind characteristics and wind energy potential in Osmaniye, Turkey. Renew. Sustain. Energy Rev. 21, 703-711 (2013)

7. Gökçek, M., Bayulken, A., Bekdemir, S.: Investigation of wind characteristics and wind energy potential in Kirklareli, Turkey. Renew. Energy 32, 1739-1752 (2007)

8. Lu, L., Yang, H., Burnett, J.: Investigation on wind power potential on Hong Kong islands: an analysis of wind power and wind turbine characteristics. Renew. Energy 27, 12 (2002)

9. Youm, I., Sarr, J., Sall, M., Ndiaye, A., Kane, M.M.: Analysis of wind data and wind energy potential along the northern coast of Senegal. Renew. Sustain. Energy Rev. 8, 95-108 (2005)

10. Irfan, U., Chaudhry, Q.Z., Chipperfield, A.J.: An evaluation of wind energy potential at KetiBankar, Pakistan. Renew. Sustain. Energy Rev. 14, 856-861 (2010)

11. Shaahid, S.M., Al-Hadhrami, L.M., Rahman, M.K.: Economic feasibility of development of wind power plants in coastal locations in Saudi Arabia: a review. Renew. Sustain. Energy Rev. 19, 589-597 (2013)

12. Durisic, Z., Mikulovic, J.: Assessment of the wind energy resource in the South Banat region, Serbia. Renew. Sustain. Energy Rev. 16, 3014-3023 (2012)

13. El Alimi, S., Maatallah, T., Dahmouni, A.W., Nasrallah, B.S.: Modeling and investigation of the wind resource in the Gulf of Tunis, Tunisia. Renew. Sustain. Energy Rev. 16, 5466-5478 (2012)

14. Maatallah, T., El Alimi, S., Dahmouni, A.W., Nasrallah, B.S.: Wind power assessment and evaluation of electricity generation in the Gulf of Tunis, Tunisia. Sustain. Cities Soc. 6, 1-10 (2013)

15. Amara, F.B., Elamouri, M., Dhifaoui, R.: Energy assessment of the first wind farm section of Sidi Daoud, Tunisia. Renew. Energy 33, 2311-2321 (2008)

16. Elamouri, M., Amar, F.B., Trabelsi, A.: Vertical characterization of the wind mode and its effect on the wind farm profitability of Sidi Daoud-Tunisia. Energy Convers. Manag. 52, 1539-1549 (2011)

17. Mohamed, A., Jamel, B.: Wind resource estimation and wind park design in El-Kef region, Tunisia. Energy 40, 348-357 (2012)

18. Colantoni, A., Allegrini, E., Boubaker, K., Longo, L., Di Giacinto, S., Biondi, P.: New insights for renewable energy hybrid photovoltaic/wind installations in Tunisia through a mathematical model. Energy Convers. Manag. 75, 398-401 (2013)

19. Elamouri, M., Ben, A.F.: Wind energy potential in Tunisia. Renew. Energy 33, 758-768 (2008)
20. Dahmouni, A.W., Salah Ben, M., Askri, F., Kerkeni, C., Nasrallah, B.S.: Assessment of wind energy potential and optimal electricity generation in Borj-Cedria, Tunisia. Renew. Sustain. Energy Rev. 15, 815-820 (2011)

21. Kaboli, S.H.A., et al.: An expression-driven approach for longterm electric power consumption forecasting. Am. J. Data Min. Knowl. Discov. 1, 16-28 (2016)

22. Hlal, M.I., et al.: NSGA-II and MOPSO based optimization for sizing of hybrid PV/wind/battery energy storage system. Int. J. Power Electron. Drive Syst. 1, 463-478 (2016)

23. Pourdaryaei, A., Mokhlis, H., Illias, H.A., Kaboli, S.H.A., Ahmad, S.: Short-term electricity price forecasting via hybrid backtracking search algorithm and ANFIS approach. IEEE Access 7, 7767477691 (2019)

24. Kaboli, S.H.A., Alqallaf, A.K.: Solving non-convex economic load dispatch problem via artificial cooperative search algorithm. Expert Syst. Appl. 128, 14 (2019)

25. Soulouknga H.M.: Contribution à l'évaluation des potentiels solaire et éolien du Tchad, Thèse Doctorat p. 137 (2018)

26. Ahmed, A.S., Hanitsch, R.: Evaluation of wind energy potential and electricity generation on the coast of Mediterranean Sea in Egypt. Renew. Energy 31, 1183-1202 (2006)

27. Soulouknga, M.H., Doka, S.Y., Revanna, N., Djongyang, N., Kofane, T.C.: Analysis of wind speed data and wind energy potential in Faya-Largeau, Chad, using Weibull distribution. Renew. Energy 121, 1-8 (2018)

28. Chellali, F., Khellaf, A., Belouchrani, A., Recioui, A.: A contribution in the actualization of wind map of Algeria. Renew. Sustain. Energy Rev. 15, 993-1002 (2011)

29. Kaabeche, A., Maïouf, B., Ibtiouen, R.: Techno-economic valuation and optimization of integrated photovoltaic/wind energy conversion system. Sol. Syst. 85, 2407-2420 (2011)

30. Gökçek, M., Genc, S.M.: Evaluation of electricity generation and energy cost of wind energy conversion systems (WECSs) in Central Turkey. Appl. Energy 86, 2731-2739 (2009)

31. Akpinar, E.K., Akpinar, S.: An assessment on seasonal analysis of wind energy characteristics and wind turbine characteristics. Energy Convers. Manag. 46, 1848-1867 (2005)

32. Mortensen, N.G., Landgerg, L., Troen, I., Petersen, E.L., Rathmann, O., Nielsen, O.: WAsP Utility Programs Ris $\emptyset-1-2261$. Ris $\varnothing$ National Library, Roskilde (2004)

33. Jowder, F.A.L.: Wind power analysis and site matching of wind turbine generators in Kingdom of Bahrain. Appl. Energy 86, 538-545 (2009)

34. Lackner, M.A., Rogers, A.L., Manwell, J.F., McGowan, J.G.: A new method for improved hub height mean wind speed estimates using short-term hub height data. Renew. Energy 35, 2340-2347 (2010)

35. Shata, A.S.A., Hanitsch, R.: Evaluation of wind energy potential and electricity generation on the coast of Mediterranean Sea in Egypt. Renew. Energy 31(8), 1183-1202 (2006)

36. Diaf, S., Notton, G.: Evaluation of electricity generation and energy cost of wind energy conversion systems in Southern Algeria. Renew. Sustain. Energy Rev. 23, 379-390 (2013)

37. Gass, V., Schmidt, J., Strauss, F., Schmid, E.: Assessing the economic wind power potential in Austria. Energy Policy 53, 323330 (2013)

Publisher's Note Springer Nature remains neutral with regard to jurisdictional claims in published maps and institutional affiliations. 